\title{
Anti-acanthamoebic activity of methanolic extract of Piper sarmentosum leaves
}

\author{
Farah Farisha Mustafa1 , Nor Farahiyah Ghazali', Habsah Mohamad², Maizatul Akma ${ }^{1 b r a h i m}{ }^{1 \star}$ and $^{2}$ \\ Nor Hafizah Zakaria ${ }^{1}$ \\ ${ }^{1}$ Department of Plant Science, Kulliyyah of Science, International Islamic University Malaysia, Jalan Sultan Ahmad Shah, \\ Bandar Indera Mahkota, 25200 Kuantan, Pahang, Malaysia. \\ ${ }^{2}$ Institute of Marine Biotechnology, Universiti Malaysia Terengganu, 21030 Kuala Nerus, Terengganu, Malaysia. \\ Email: maizatulakma@iium.edu.my
}

Received 10 May 2021; Received in revised form 27 July 2021; Accepted 22 August 2021

\begin{abstract}
Aims: Piper sarmentosum or locally known as Kaduk, is a tropical herb plant that was investigated for its phenolic content by previous researchers. The present study aimed at the analysis of crude methanolic extract of $P$. sarmentosum leaves for phenolic compounds identification and its anti-amoebic properties against pathogenic Acanthamoeba castellanii.

Methodology and results: Folin-Ciocalteu assay was used to determine $P$. sarmentosum leaves methanolic extract (PSLME)'s total phenolic content (TPC). The extract was further characterized by using gas chromatography-mass spectrometry (GC-MS), reverse phase-high performance liquid chromatography (RP-HPLC) and liquid chromatographymass spectrometry (LC-MS) analyses to determine the chemical constituents in methanolic PSLME extract. The cytotoxicity of the extract was evaluated through the determination of inhibition concentration for half of cell population ( $\left.\mathrm{IC}_{50}\right)$ of pathogenic $A$. castellanii followed by cell morphological analysis using inverted light and scanning electron microscopies. Acridine-orange/Propidium iodide (AOPI) staining was also conducted to determine the integrity of cell membrane for quantitative analysis. The results demonstrated that the TPC from PSLME was $142.72 \mathrm{mg}$ [GAE]/g with a total of 33 phenolic compounds identified. The $\mathrm{IC}_{50}$ value obtained for $A$. castellanii was low $(74.64 \mu \mathrm{g} / \mathrm{mL})$ which indicates promising anti-acanthamoebic activity. Microscopy analyses showed that the plant extract caused cells encystment, in which exhibited by distinctive morphological changes on the cells shape and organelle, as well as shortening of acanthopodia. The dual staining and its quantitative analysis prove compromised membrane integrity in the treated amoeba.
\end{abstract}

Conclusion, significance and impact of study: This finding provides the evidence that PSLME contains active phenolic compounds contributing to the anti-acanthamoebic activity on pathogenic Acanthamoeba species.

Keywords: Piper sarmentosum, phenolic compound, chromatography, Acanthamoeba castellanii, anti-amoeba

\section{INTRODUCTION}

Acanthamoeba castellanii is a free-living protozoan amoeba that lives as bacterial consumer in natural environment such as seawater, river, lakes and contaminated water sources (Tsvetkova et al., 2004; Lorenzo-Morales et al., 2005). This amoeba can easily infect human through lower respiratory tract or ulcerated and broken skins which could produce toxins that can be lethal (Siddiqui and Khan, 2012). These infections could progress to chronic diseases such as granulomatous amoebic encephalitis, serious infection of the brain and spinal cord, as well as Acanthamoeba keratitis, which is a vision threatening keratitis in human involving $A$. castellanii (Kamel et al., 2005).

Phenolic compounds constitute major secondary metabolites in plants as they play important roles for the plant protection against physical pressures such as microbial pathogens, insects and harsh environment condition (Khoddami et al., 2013). Plant phenolics comprise of many subclasses such as simple phenols, coumarins, lignins, lignans, tannins, benzoic acid, cinnamic acid, phenolic acids and flavonoids (Soto-Vaca et al., 2012; Khoddami et al., 2013). Over decades, phenolic compounds are discovered to provide pharmacological properties including anti-inflammatory, anti-allergenic, anti-thrombotic, anti-artherogenic and antimicrobial against bacteria, fungi and microalgae (Dykes and Rooney, 2007; Zakaria et al., 2010; Hussain et al., 2012).

Piper sarmentosum or locally known as Kaduk, is a terrestrial herb that has been used as traditional food and for many traditional medicinal purposes. The plant leaves are commonly used as raw vegetable whilst the whole 
plant is effective as remedy to treat minor ailments such as coughs, headache, toothache, influenza, asthma and feet fungoid dermatitis (Atiax et al., 2011). It is widely distributed in Southeast Asia countries including Thailand, Indonesia, Philippines and Malaysia. Recent researches proved that some of the plant solvents-based extracts showed antimicrobial properties against wide ranges of microorganisms especially bacteria, microalgae, protozoa and fungi (Rahman et al., 2014a; 2016). These findings reported that the demonstrated antimicrobial properties of the plant associated with high amount of phenolic content. However, the specific potential of phenolic compounds from $P$. sarmentosum against $A$. castellanii is yet to be investigated. Hence, this research aimed to identify the phenolic substances present in $P$. sarmentosum leaves crude methanolic extract and to evaluate the cytotoxicity effects toward pathogenic $A$. castellanii.

\section{MATERIALS AND METHODS}

\section{Plant material}

Fresh leaves of $P$. sarmentosum were collected from the botanical garden of Glasshouse and Nursery Complex, International Islamic University Malaysia (IIUM) Kuantan Campus, Pahang. The taxonomic identification was performed by Dr. Shamsul Khamis from Universiti Kebangsaan Malaysia, and the voucher specimen (No: PIIUM 0239-3) was deposited in the Herbarium at Kulliyyah of Pharmacy, IIUM. Samples were frozen at -80 ${ }^{\circ} \mathrm{C}$ for $24 \mathrm{~h}$ and freeze dried for three days.

\section{Extraction of phenolic compounds}

Extraction of phenolic compounds from $P$. sarmentosum leaves was carried out using improved maceration technique based on Rahman et al. (2014a). Powdered leaves $(350 \mathrm{mg})$ were dissolved in $25 \mathrm{~mL}$ of pure methanol. The solution was sonicated in a water bath sonicator at $35{ }^{\circ} \mathrm{C}$ for $40 \mathrm{~min}$. A $10 \mathrm{~mL}$ of $0.01 \mathrm{M}$ hydrochloric acid was then added slowly to the solution over $5 \mathrm{~min}$. The solution was transferred to $100 \mathrm{~mL}$ round bottomed flask and stirred using a magnetic stirrer under nitrogen condition at $35{ }^{\circ} \mathrm{C}$ for $16 \mathrm{~h}$. After cooling and filtering through Whatman No. 1, the methanol solvent was evaporated to dryness using a rotary evaporator at vacuum pressure of $337 \mathrm{mb}$ in a water bath at $60^{\circ} \mathrm{C}$.

\section{Determination of total phenolic content}

Total phenolic content (TPC) in the plant extract was determined according to Folin-Ciocalteu method (Pieroni et al., 2011). Samples were evaluated at final concentration of $0.1 \mathrm{mg} / \mathrm{mL}$ after dilution with methanol. A total volume of $0.5 \mathrm{~mL}$ of extract aliquot was mixed with $2.5 \mathrm{~mL}$ Folin-Ciocalteu reagent (previously diluted with distilled water $1: 10, \mathrm{v} / \mathrm{v}$ ) and $7.5 \mathrm{~mL}$ aqueous sodium carbonate solution. The tube was incubated at room temperature for $120 \mathrm{~min}$ for color development. Absorbance was measured spectrometrically at $760 \mathrm{~nm}$.
TPC was determined by interpolation of the absorbance of the samples against a linear calibration curve made with gallic acid standard ranged from 1 to $500 \mu \mathrm{g} / \mathrm{mL}$. TPC was expressed as $\mathrm{mg}$ gallic acid equivalents (GAE) per $g$ of crude extract. The samples were made in triplicates.

\section{Gas chromatography mass spectrometry (GC-MS) analysis}

The characterization of phenolic compounds in $P$. sarmentosum leaves methanolic extract (PSLME) was performed through gas chromatography mass spectrometry (GC-MS) analysis based on the modified method from Rahman et al. (2014a). The plant crude extract was diluted in liquid chromatography (LC) grade methanol to obtain the final concentration of $5 \mathrm{mg} / \mathrm{mL}$. The diluted solution was filtered through a sterile nylon membrane (pore size of $0.45 \mu \mathrm{m}$ and diameter of $13 \mathrm{~mm}$ ). GC-MS analysis of the plant extract was conducted on Clarus $^{\mathrm{TM}} \mathrm{SQ} 8 \mathrm{GC} / \mathrm{MS}$ instrument equipped with Elite $5 \mathrm{MS}$ capillary column $(30 \mathrm{~m}$ length, $0.25 \mu \mathrm{m}$ film thickness, $0.25 \mathrm{~mm}$ inner diameter, coupled with a Clarus $600 \mathrm{C}$ mass spectrometer. $99.9 \%$ purified helium gas was used as the carrier gas at $68.8 \mathrm{kPa}$ pressure maintained at the flow rate of $1.0 \mathrm{~mL} / \mathrm{min}$. The ionizing energy was set at $70 \mathrm{eV}$ and the mass range at $\mathrm{m} / \mathrm{z} 25-700$. The oven temperature condition was programmed from $70^{\circ} \mathrm{C}$ (hold for $5 \mathrm{~min}$ ) to $280{ }^{\circ} \mathrm{C}$ at a rate of $7^{\circ} \mathrm{C} / \mathrm{min}$. The total program run time was $46 \mathrm{~min}$. Phenolic compositions were identified by comparing the mass spectrums and retention time of authentic compounds in the National Institute of Standards and Technology (NIST) and Wiley libraries. The composition of each detected phenolic compounds was expressed as the percentage of the compound peak area in the total extract.

\section{Reverse phase-high performance liquid chromatography (RP-HPLC) analysis}

PSLME was diluted in LC grade methanol to produce the working concentration of $2.5 \mathrm{mg} / \mathrm{mL}$. The standards used for reverse phase-high performance liquid chromatography (RP-HPLC) analysis of phenolic compounds were gallic acid, tannic acid, quercetin and naringenin. Quantification of phenolic compounds was performed by using an external standard method, which was achieved via calibration curves generated from the serial dilutions of standard solution with concentration sequences from 1 to $200 \mu \mathrm{g} / \mathrm{g}$. All standards were filtered through $0.45 \mu \mathrm{m}$ pore size sterile nylon membrane filter preceding the analysis. The linear calibration charts that were comprised of the area under the peak versus standard concentrations were subsequently used for phenolic compounds quantification according to their corresponding standards.

Qualitative and quantitative analysis for phenolic compounds in $P$. sarmentosum through RP-HPLC was performed using FX-15 HPLC system. The instrument was equipped with FX-15 UHPLC pump, FX-UV/vis 
UHPLC detector, an auto sampler and vacuum degasser. Separation of the phenolic compounds was achieved using LiChosorb C-18 HPLC analytical column (5 $\mu \mathrm{m}$ diameter, $3.0 \mu \mathrm{m}$ inner diameter, $250 \mathrm{~mm}$ length). The analysis was programmed based on Rahman et al. (2014b) with minor optimization. Separation of individual phenolic compounds was performed by isocratic elution of the mobile phase in binary mode and the column temperature was maintained at $28{ }^{\circ} \mathrm{C}$ throughout analysis. Prior to analysis, the column was washed with HPLC grade acetonitrile for $30 \mathrm{~min}$ and was reconditioned with HPLC grade methanol for 15 min between runs. The details of the isocratic condition with respect to each targeted phenolic compound are described in Table 1. Each solvent was filtered through $0.45 \mu \mathrm{m}$ membrane filter and degassed in a water bath sonicator for $15 \mathrm{~min}$ before used. The four standards were pre-analyzed to determine the compound retention times, in order to compare to the sample extracts under the same conditions. All of the standards and samples were injected into the system with injection volume of 10 $\mu \mathrm{L}$. Chromatograms, linear calibration curve of standard and quantitative measurements of phenolic compounds peak area were recorded and processed by Chromera and TotalChrom software (version 6.3).

\section{LC-MS analysis}

The identification of phenolic compounds through liquid chromatography mass spectrometry (LC-MS) was performed using Ultra Performance Liquid Chromatograhy (UPLC) coupled to Vion IMS QToF Mass Spectrometer. The system featured XS Ion Optics and Quadrupole Time-of-Flight (QToF) as the detection system. The phenolic compounds chromatographic separation was achieved by using ACQUITY UPHLC $B$ HSS T3 column. The low collision energy was set at $4 \mathrm{eV}$ and the high collision ramp started at $10 \mathrm{eV}$ and ended at $45 \mathrm{eV}$. The interface used in the analysis was Electron Spray lonization (ESI) ionization source type with the source temperature of $120^{\circ} \mathrm{C}$. Pure nitrogen $(99.9 \%$ ) was used as desolvation gas at the temperature of $550{ }^{\circ} \mathrm{C}$, with the flow rate of $800 \mathrm{~L} / \mathrm{h}$. The mobile phase used to move the solute through the column was LC grade water (Solvent A) and LC grade acetonitrile (Solvent B) and the flow rate was maintained at $0.5 \mathrm{~mL} / \mathrm{min}$. The program was set in gradient mode with the following conditions as described in Table 2. The column temperature was maintained at $40{ }^{\circ} \mathrm{C}$ throughout analysis. The spectra were recorded in negative mode within the mass range of 100 to $1000 \mathrm{~m} / \mathrm{z}$. The identification of individual compounds detected was based on the retention times and theoretical exact mass driven by UNIFI scientific information system (version 1.8).

Table 2: The gradient condition of LC-MS analysis.

\begin{tabular}{lcc}
\hline Time $(\min )$ & Composition of mobile phase solvent (\%) \\
\cline { 2 - 3 } & $\begin{array}{c}\text { Water } \\
\text { (Solvent A) }\end{array}$ & $\begin{array}{c}\text { Acetonitrile } \\
\text { (Solvent B) }\end{array}$ \\
\hline $0.0-5.0$ & 99 & 1 \\
$5.0-16.0$ & 65 & 35 \\
$16.0-18.0$ & 0 & 100 \\
$18.0-20.0$ & 99 & 1 \\
\hline
\end{tabular}

\section{Determination of inhibition concentration value $\left(\mathrm{IC}_{50}\right)$ for half of cell population against $\boldsymbol{A}$. castellanii}

Acanthamoeba castellanii strain 1501/2A of Culture Collection of Algae and Protozoa (CCAP), UK was used throughout this study. Approximately $10^{4} \mathrm{cell} / \mathrm{mL}$ was seeded in each well of sterile 96-well plate filled with peptone-yeast-glucose (PYG) culture medium. Cells were incubated at $30^{\circ} \mathrm{C}$ for $24 \mathrm{~h}$. The cells were treated with $P$. sarmentosum leaves methanolic extract (PSLME) with different concentrations ranging from 3.91 to $1000 \mu \mathrm{g} / \mathrm{mL}$ from two-fold dilution series. The determination of halfmaximal inhibitory concentration (IC 50$)$ was conducted using eosin dye method founded by Wright et al. (1988). The absorbance of final was measured at $492 \mathrm{~nm}$ using Multiskan $^{\mathrm{TM}}$ GO Microplate Spectrophotometer. The percentage of cell growth inhibition was plotted against the logarithm of the extract sample concentrations in GraphPad Prism software to obtain non-linear sigmoidal dose-response curve, where the extract concentration

Table 1: The isocratic condition of RP-HPLC analysis with respect to target compounds.

\begin{tabular}{|c|c|c|c|c|c|c|c|}
\hline \multirow{2}{*}{$\begin{array}{c}\text { Target } \\
\text { compounds }\end{array}$} & \multicolumn{4}{|c|}{ Mobile phase } & \multirow{2}{*}{$\begin{array}{l}\text { Ratio } \\
(\mathrm{v} / \mathrm{v})\end{array}$} & \multirow{2}{*}{$\begin{array}{l}\text { Flow rate } \\
\text { (mL/min) }\end{array}$} & \multirow{2}{*}{$\begin{array}{l}\text { Wavelength } \\
(\mathrm{nm})\end{array}$} \\
\hline & Solvent A & Solvent B & Solvent C & Solvent D & & & \\
\hline Gallic acid & $\begin{array}{c}\text { Pure LC grade } \\
\text { methanol }\end{array}$ & $\begin{array}{c}1 \% \text { trifluoroacetic } \\
\text { acid in ultrapure } \\
\text { water }\end{array}$ & & & $\begin{array}{c}A: B \\
80: 20\end{array}$ & 0.8 & 280 \\
\hline Tannic acid & $\begin{array}{l}\text { Pure LC grade } \\
\text { methanol }\end{array}$ & $\begin{array}{c}1 \% \text { trifluoroacetic } \\
\text { acid in ultrapure } \\
\text { water }\end{array}$ & & & $\begin{array}{c}A: B \\
70: 30\end{array}$ & 0.7 & 270 \\
\hline Naringenin & $\begin{array}{l}\text { Pure LC grade } \\
\text { methanol }\end{array}$ & $\begin{array}{c}1 \% \text { trifluoroacetic } \\
\text { acid in ultrapure } \\
\text { water }\end{array}$ & & & $\begin{array}{c}A: B \\
90: 10\end{array}$ & 0.8 & 280 \\
\hline Quercetin & $\begin{array}{c}\text { Pure LC grade } \\
\text { methanol }\end{array}$ & & $\begin{array}{l}\text { LC grade } \\
\text { acetonitrile }\end{array}$ & $\begin{array}{l}\text { Ultrapure } \\
\text { water }\end{array}$ & $\begin{array}{c}A: C: D \\
5: 50: 45\end{array}$ & 0.8 & 370 \\
\hline
\end{tabular}


that inhibited $50 \%\left(\mathrm{IC}_{50}\right)$ of Acanthamoeba population was determined. Positive control, chlorhexidine $(0.25 \%)$ used the same protocol as above.

\section{Microscopy observation of Acanthamoeba cell morphology}

Cells concentration of $1 \times 10^{5}$ cells $/ \mathrm{mL}$ was treated with PSLME at their $\mathrm{IC}_{50}$ values in $\mathrm{T}-25$ culture flask and incubated in $30{ }^{\circ} \mathrm{C}$ for $72 \mathrm{~h}$. After incubation, the cell morphology was observed directly under Olympus IX51 inverted light microscope. The cell images were acquired and processed using Analysis LS Research software (version 2.6) connected to the microscope. The image of the extract-treated $A$. castellanii was compared to the positive (chlorhexidine) and negative (cells without treatment) controls. Each treatment was prepared in triplicates.

\section{Measurement of cell confluence in axenic culture}

Extract-treated $A$. castellanii was subjected to visual examination of adherent cells confluence. The technique was based on Busschots et al. (2015). A cardboard cover was designed to fit the bottom surface of T-25 flask having two windows located close to the top and bottom of the flask surface with the area measurement of $1 \mathrm{~cm}^{2}$. The cardboard was glued underneath the culture flask. Upon viewing, $4 \times$ objective lens was placed over the cardboard window and was adjusted to focus on the cell nuclei. Photographs were taken from each window, representing an approximate confluence value of the whole flask. Measurement of adherent cells confluence was conducted using Image $\mathrm{J}$ software (version 10.2) (Fiji, USA) producing an area fraction (AF) output.

\section{Scanning electron microscopy (SEM)}

Cells density of $1 \times 10^{4}$ cells $/ \mathrm{mL} A$. castellanii which treated with PSLME at $\mathrm{IC}_{50}$ value in a $30^{\circ} \mathrm{C}$ incubator for $72 \mathrm{~h}$ was observed by SEM. The $A$. castellanii cells were subjected to dry fixation based on Nakisah et al. (2012). After incubation, the culture medium was carefully replaced with $2.5 \%(\mathrm{v} / \mathrm{v})$ gluteraldehyde in phosphate buffered saline (PBS) solution for $1 \mathrm{~h}$ at $30^{\circ} \mathrm{C}$. The cover slips of which contained the amoeba cells were then gently washed with sterile PBS three times. The treatment was followed with post-fixation using $1 \%$ osmium tetraoxide that was previously diluted in PBS solution for $1 \mathrm{~h}$ at $30^{\circ} \mathrm{C}$ in dark condition. The cover slips were then rinsed with PBS for three times. Following that, the cell specimens were dehydrated in graded series of ethanol (30\%, 40\%, 50\%, 60\%, 70\%, 80\%, 90\% and $100 \%)$ for 5 min in each soaking. Final dehydration in $100 \%$ ethanol was repeated twice. Later, dehydrated Acanthamoeba specimens were subjected to critical point drying by adding few drops of hexamethyldisilazane. The cover slips were carefully mounted on a $13 \mathrm{~mm}$ aluminium stub by using the double-sided adhesive conductive carbon sticky tape to maintain the position of the cover slips on the SEM stub. Prior to visual examination under SEM, the specimen stub was coated with gold by JEOL Smart Coater. Similar protocol was applied for the negative and positive controls. Scanning Electron Microscope (JEOL JSM-6360 LV) was operated at 5 to $20 \mathrm{kV}$ accelerating voltage.

\section{Determination of cell membrane integrity}

The cell suspension in PBS was centrifuged at $800 \mathrm{rpm}$ for $3 \mathrm{~min}$ using Minispin microcentrifuge (Eppendorf, Germany). The supernatant was then discarded, and the pellets were resuspended in $50 \mu \mathrm{L}$ of Acridineorange/Propidium iodide $(\mathrm{AOPI})(1: 1 \mathrm{v} / \mathrm{v})$. The cell suspensions were observed under an upright binocular microscope (Leica Dmire LB2, Germany). Then, 100 Acanthamoeba cells were randomly calculated on each slide of three replicates and were classified based on their membrane integrity. Green cells were classified as intact cells while the cells with red or orange precipitates were classified as cells with non-intact membrane. Statistical analysis of t-test (SPSS version 17.0) (IBM, USA) was carried out to determine whether there was significant difference in the effects of PSLME on the membrane integrity between the treated and untreated cells. $p<0.05$ was considered as statistically significant.

\section{RESULTS}

\section{Total phenolic content}

Calculation of the total phenolic content was achieved from a linear calibration curve of gallic acid standard with coefficient of determination $\left(R^{2}\right)$ equals to 0.998 . By using the linear regression equation, high total phenolic content was measured which was $142.72 \mathrm{mg}[\mathrm{GAE}] / \mathrm{g}$ of crude extract.

\section{Gas chromatography mass spectrometry (GC-MS) analysis}

Gas chromatography mass spectrometry (GC-MS) analysis of PSLME showed eight peaks in its total chromatogram as shown in Figure 1. The compounds mass spectrums and retentions were compared with the National Institute of Standards and Technology (NIST) and Wiley libraries and revealed that six peaks represented six phenolic compounds, while the other two peaks were unidentified. The identified phenolic compounds are listed in Table 3 . The relative amount of the compound detected was expressed as percentage of peak area (total area normalization). a-Asarone, a phenylpropanoid was the major chemical that constituted $59 \%$ of the total compound content while, its isomer, Basarone only constituted $1.9 \%$ of the extract. Besides, PLSME also contains $1.5 \%$ of another phenylpropanoid called benzenepropanoic acid, methyl ester. Meanwhile, the compositions of phenylpropenes detected were elemicine $(33.3 \%)$, myristicine $(2.8 \%)$ and methyleugenol $(1.5 \%)$. 


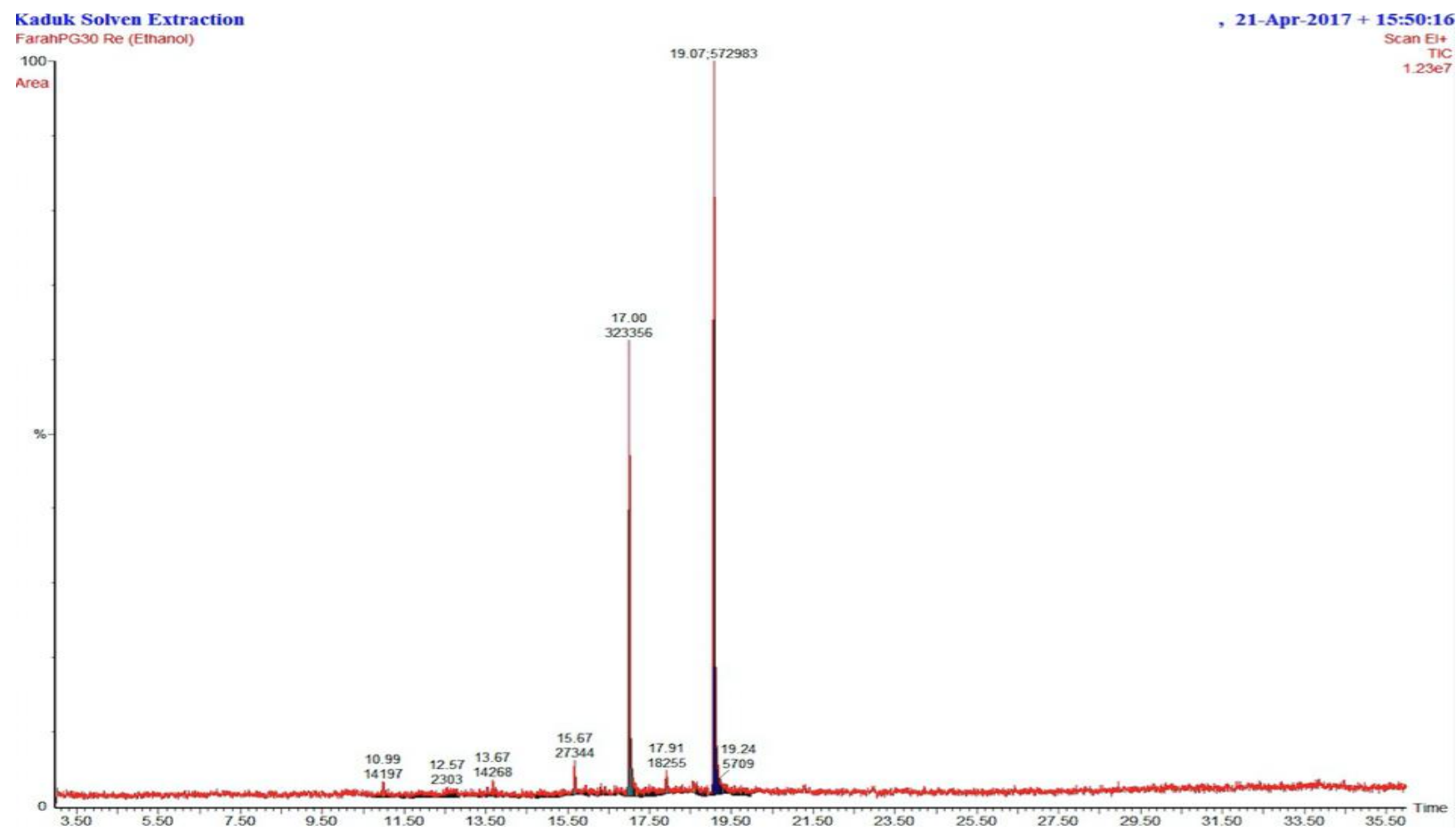

Figure 1: GC-MS chromatogram of phenolic compounds detected in methanolic extract of $P$. sarmentosum leaves. Retention time 19.07: a-Asarone, 17.91: B-Asarone, 17.00: Elemicine, 15.67: Myristicine, 13.67: Methyleugenol, 10.99: Benzenepropanoic acid, methyl ester.

Table 3: Chemical constituents detected in methanolic extract of $P$. sarmentosum leaves from GC-MS analysis.

\begin{tabular}{llllccc}
\hline No. & Name of compound & $\begin{array}{l}\text { Chemical } \\
\text { formula }\end{array}$ & $\begin{array}{l}\text { Class of phenolic } \\
\text { compound }\end{array}$ & $\begin{array}{c}\text { Retention time } \\
(\mathrm{min})\end{array}$ & $\begin{array}{c}\text { Exact mass } \\
(\mathrm{g} / \mathrm{mol})\end{array}$ & $\begin{array}{c}\text { Peak area } \\
(\%)\end{array}$ \\
\hline 1 & a-Asarone & $\mathrm{C}_{12} \mathrm{H}_{16} \mathrm{O}_{3}$ & Phenylpropanoid & 19.07 & 208.1099 & 59.046 \\
2 & B-Asarone & $\mathrm{C}_{12} \mathrm{H}_{16} \mathrm{O}_{3}$ & Phenylpropanoid & 17.91 & 208.1099 & 1.881 \\
3 & Elemicine & $\mathrm{C}_{12} \mathrm{H}_{16} \mathrm{O}_{3}$ & Phenylpropene & 17.00 & 208.1099 & 33.322 \\
4 & Myristicine & $\mathrm{C}_{11} \mathrm{H}_{12} \mathrm{O}_{3}$ & Phenylpropene & 15.67 & 192.0786 & 2.818 \\
5 & Methyleugenol & $\mathrm{C}_{11} \mathrm{H}_{14} \mathrm{O}_{2}$ & Phenylpropene & 13.67 & 178.0994 & 1.470 \\
6 & $\begin{array}{l}\text { Benzenepropanoic acid, } \\
\text { methyl ester }\end{array}$ & $\mathrm{C}_{10} \mathrm{H}_{12} \mathrm{O}_{2}$ & Phenylpropanoid & 10.99 & 164.0837 & 1.463 \\
\hline
\end{tabular}

Table 4: Composition of phenolic compounds in methanolic extract of $P$. sarmentosum leaves detected from RP-HPLC analysis.

\begin{tabular}{llllccc}
\hline No. & Name of compound & $\begin{array}{l}\text { Chemical } \\
\text { formula }\end{array}$ & $\begin{array}{l}\text { Class of phenolic } \\
\text { compound }\end{array}$ & $\begin{array}{c}\text { Retention time } \\
(\mathrm{min})\end{array}$ & $\begin{array}{c}\text { Exact mass } \\
(\mathrm{g} / \mathrm{mol})\end{array}$ & $\begin{array}{c}\text { Amount of } \\
\text { compound }(\mu \mathrm{g} / \mathrm{g})\end{array}$ \\
\hline 1 & Gallic acid & $\mathrm{C}_{7} \mathrm{H}_{6} \mathrm{O}_{5}$ & Phenolic acid & 3.32 & 170.12 & 115.50 \\
2 & Tannic acid & $\mathrm{C}_{76} \mathrm{H}_{52} \mathrm{O}_{46}$ & Phenolic acid & 3.70 & 1701.21 & 62.50 \\
3 & Naringenin & $\mathrm{C}_{15} \mathrm{H}_{12} \mathrm{O}_{5}$ & Flavonoid & 3.89 & 272.26 & 3.56 \\
4 & Quercetin & $\mathrm{C}_{15} \mathrm{H}_{10} \mathrm{O}_{7}$ & Flavonoid & 4.38 & 302.24 & 0.29 \\
\hline
\end{tabular}

Reverse phase-high performance liquid $(115.50 \mu \mathrm{g} / \mathrm{g})$, followed by tannic acid (62.5 $\mu \mathrm{g} / \mathrm{g})$, chromatography (RP-HPLC) analysis

The RP-HPLC analysis of PSLME revealed that gallic acid was the major phenolic compound constituent naringenin $(3.56 \mu \mathrm{g} / \mathrm{g})$ and quercetin $(0.29 \mu \mathrm{g} / \mathrm{g})$ as presented in Table 4. Figure 2 shows the representative chromatograms of compounds detection in the plant extract with respect to the standard retention times. 
Malays. J. Microbiol. Vol 17(5) 2021, pp. 525-538 DOI: http://dx.doi.org/10.21161/mjm.211170
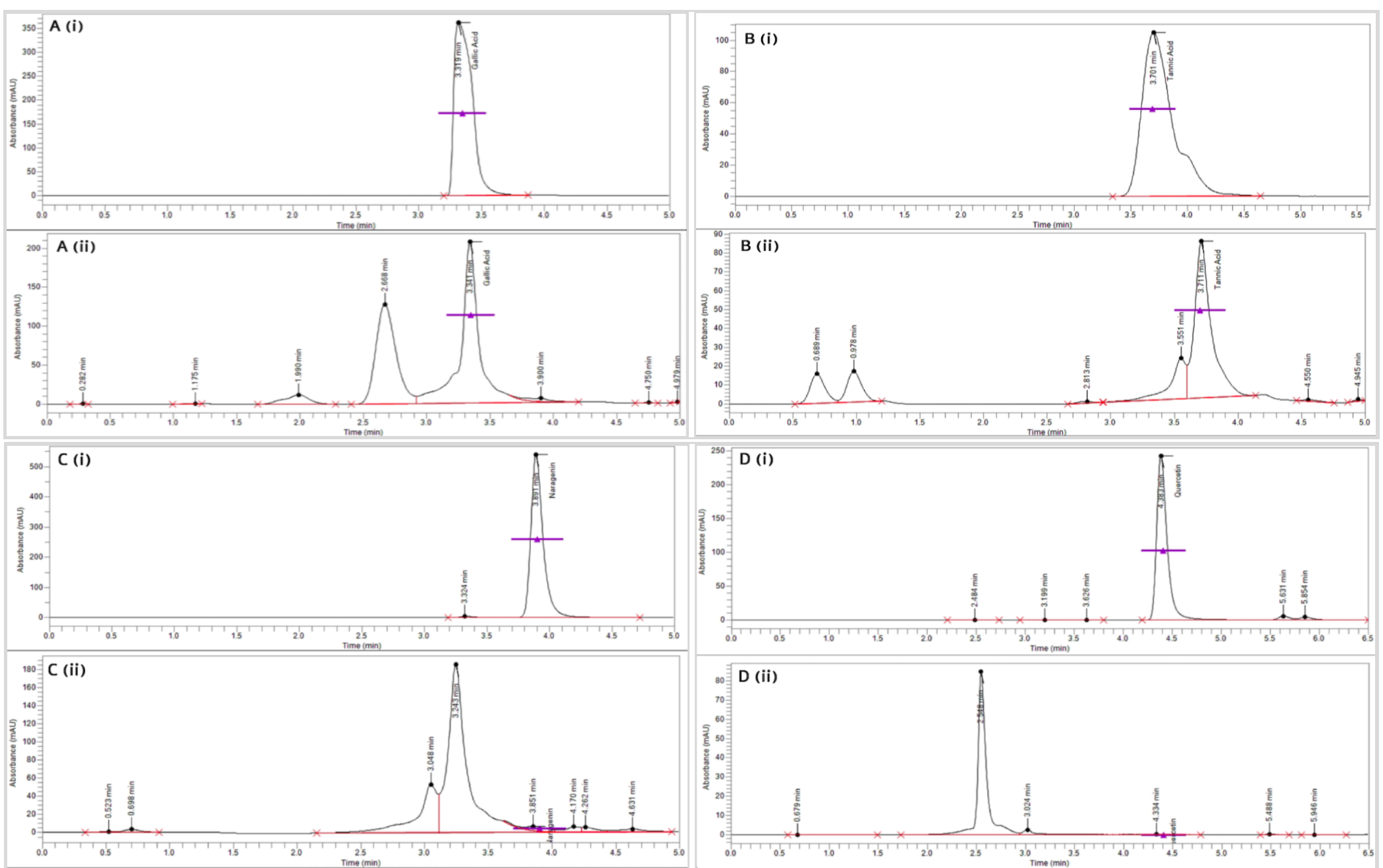

Figure 2: Representative chromatograms of (i) standard solution and (ii) P. sarmentosum leaves methanolic extract from RP-HPLC analysis. (A) Gallic acid (B) Tannic acid, (C) Naringenin and (D) Quercetin. 


\section{LC-MS analysis}

Through LC-MS analysis, a total of 23 phenolic compounds were identified in $P$. sarmentosum leaves methanolic extract. The list of identified compounds is presented in Table 5. Based on the calculation of compound peak area, kuzubutenolide A was the largest constituent in the total extract $(30 \%)$ while the least constituent was aspidinol of $0.619 \%$ of the crude extract. The total chromatogram of phenolic compounds detected in $P$. sarmentosum leaves methanolic extract (PSLME) is shown in Figure 3.

Table 5: The list of phenolic compounds identified in P. sarmentosum leaves methanolic extract from LC-MS analysis.

\begin{tabular}{|c|c|c|c|c|c|c|}
\hline No. & Name of compound & $\begin{array}{l}\text { Chemical } \\
\text { formula }\end{array}$ & $\begin{array}{l}\text { Class of phenolic } \\
\text { compound }\end{array}$ & $\begin{array}{l}\text { Retention time } \\
\quad(\min )\end{array}$ & $\begin{array}{c}\text { Exact mass } \\
(\mathrm{g} / \mathrm{mol})\end{array}$ & $\begin{array}{c}\text { Peak area } \\
(\%)\end{array}$ \\
\hline 1 & Isoduartin & $\mathrm{C}_{18} \mathrm{H}_{20} \mathrm{O}_{6}$ & Isoflavan & 13.1 & 377.124 & 0.962 \\
\hline 2 & 1-Galloyl-glucose & $\mathrm{C}_{13} \mathrm{H}_{16} \mathrm{O}_{10}$ & Tannin & 3.728 & 331.067 & 6.678 \\
\hline 3 & Aspidinol & $\mathrm{C}_{12} \mathrm{H}_{16} \mathrm{O}_{4}$ & $\begin{array}{l}\text { Aenicide } \\
\text { phloroglucinol } \\
\text { derivatives }\end{array}$ & 8.835 & 269.102 & 0.619 \\
\hline 4 & Renifolin & $\mathrm{C}_{18} \mathrm{H}_{24} \mathrm{O}_{7}$ & $\begin{array}{l}\text { Prenylated } \\
\text { chalcone } \\
\text { (flavonoid) }\end{array}$ & 13.597 & 397.149 & 0.661 \\
\hline 5 & Tribulusamide A & $\mathrm{C}_{36} \mathrm{H}_{36} \mathrm{~N}_{2} \mathrm{O}_{8}$ & Lignanamides & 12.665 & 669.245 & 2.102 \\
\hline 6 & Tribulusamide B & $\mathrm{C}_{36} \mathrm{H}_{34} \mathrm{~N}_{2} \mathrm{O}_{9}$ & Lignanamides & 0.681 & 683.225 & 1.01 \\
\hline 7 & Forsythoside A & $\mathrm{C}_{29} \mathrm{H}_{36} \mathrm{O}_{15}$ & Phenylpropanoid & 12.242 & 623.198 & 0.761 \\
\hline 8 & N-trans-Coumaroyltaramine & $\mathrm{C}_{17} \mathrm{H}_{17} \mathrm{NO}_{3}$ & $\begin{array}{l}\text { Phenylpropenic } \\
\text { acid }\end{array}$ & 9.66 & 282.114 & 0.735 \\
\hline 9 & $\begin{array}{l}2,3,5,4 \text { '- } \\
\text { Tetrahydroxystilbene-2-O- } \\
\text { (6"-O- } \alpha-D-\text {-glucopyranosyl)- } \beta \text { - } \\
\text { D-glucopyranoside }\end{array}$ & $\mathrm{C}_{26} \mathrm{H}_{32} \mathrm{O}_{14}$ & $\begin{array}{l}\text { Stilbene (phenolic } \\
\text { glycoside) }\end{array}$ & 10.386 & 567.172 & 3.572 \\
\hline 10 & $\begin{array}{l}2,3,5,4^{\prime}- \\
\text { Tetrahydroxystilbene-2-O- } \beta \text { - } \\
\text { D-glucopyranoside }\end{array}$ & $\mathrm{C}_{20} \mathrm{H}_{22} \mathrm{O}_{9}$ & $\begin{array}{l}\text { Stilbene (phenolic } \\
\text { glycoside) }\end{array}$ & 10.47 & 405.119 & 1.1 \\
\hline 11 & $\begin{array}{l}2,4,6- \\
\text { Trihydroxyacetophenone-2,4- } \\
\text { di-O- } \beta \text {-D-glucopyranoside }\end{array}$ & $\mathrm{C}_{20} \mathrm{H}_{28} \mathrm{O}_{14}$ & $\begin{array}{l}\text { Phloroglucinol } \\
\text { (phenolic } \\
\text { glycoside) }\end{array}$ & 4.976 & 491.141 & 3.943 \\
\hline 12 & Cimidahurine & $\mathrm{C}_{14} \mathrm{H}_{20} \mathrm{O}_{8}$ & $\begin{array}{l}\text { Amorphous } \\
\text { phenolic } \\
\text { glycosides }\end{array}$ & 3.632 & 315.108 & 13.136 \\
\hline 13 & 2'-Acetylacteoside & $\mathrm{C}_{31} \mathrm{H}_{38} \mathrm{O}_{16}$ & $\begin{array}{l}\text { Phenylethanoid } \\
\text { glycosides }\end{array}$ & 10.941 & 665.21 & 4.737 \\
\hline 14 & Cistanoside A & $\mathrm{C}_{36} \mathrm{H}_{48} \mathrm{O}_{20}$ & $\begin{array}{l}\text { Phenylethanoid } \\
\text { glycosides }\end{array}$ & 0.815 & 845.272 & 2.085 \\
\hline 15 & Cistanoside $\mathrm{H}$ & $\mathrm{C}_{22} \mathrm{H}_{32} \mathrm{O}_{13}$ & $\begin{array}{l}\text { Phenylethanoid } \\
\text { glycosides }\end{array}$ & 8.047 & 503.177 & 1.273 \\
\hline 16 & Decaffeoylacteoside & $\mathrm{C}_{20} \mathrm{H}_{30} \mathrm{O}_{12}$ & $\begin{array}{l}\text { Phenylethanoid } \\
\text { glycosides }\end{array}$ & 9.284 & 461.166 & 0.641 \\
\hline 17 & Tubuloside E & $\mathrm{C}_{31} \mathrm{H}_{38} \mathrm{O}_{15}$ & $\begin{array}{l}\text { Phenylethanoid } \\
\text { glycosides }\end{array}$ & 13.408 & 649.215 & 0.594 \\
\hline 18 & Meliadanoside B & $\mathrm{C}_{15} \mathrm{H}_{20} \mathrm{O}_{8}$ & $\begin{array}{l}\text { Phenylpropanetriol } \\
\text { glycosides }\end{array}$ & 11.975 & 327.111 & 1.045 \\
\hline 19 & Kuzubutenolide A & $\mathrm{C}_{23} \mathrm{H}_{24} \mathrm{O}_{10}$ & Phenolic glucoside & 7.62 & 505.135 & 30.612 \\
\hline 20 & Caesalpins P & $\mathrm{C}_{16} \mathrm{H}_{12} \mathrm{O}_{6}$ & $\begin{array}{l}\text { Phenolic cassane } \\
\text { diterpenoids } \\
\text { (flavonoid) }\end{array}$ & 15.097 & 299.056 & 2.678 \\
\hline 21 & Coniferol & $\mathrm{C}_{10} \mathrm{H}_{12} \mathrm{O}_{3}$ & $\begin{array}{l}\text { Phenolic cinnamic } \\
\text { alcohol }\end{array}$ & 10.24 & 179.071 & 1.414 \\
\hline 22 & Darendoside A & $\mathrm{C}_{19} \mathrm{H}_{28} \mathrm{O}_{11}$ & $\begin{array}{l}\text { Phenethyl alcohol } \\
\text { glycosides }\end{array}$ & 5.565 & 431.156 & 0.834 \\
\hline 23 & Feroxin A & $\mathrm{C}_{17} \mathrm{H}_{24} \mathrm{O}_{8}$ & Anthocyanin & 6.12 & 401.145 & 10.192 \\
\hline
\end{tabular}




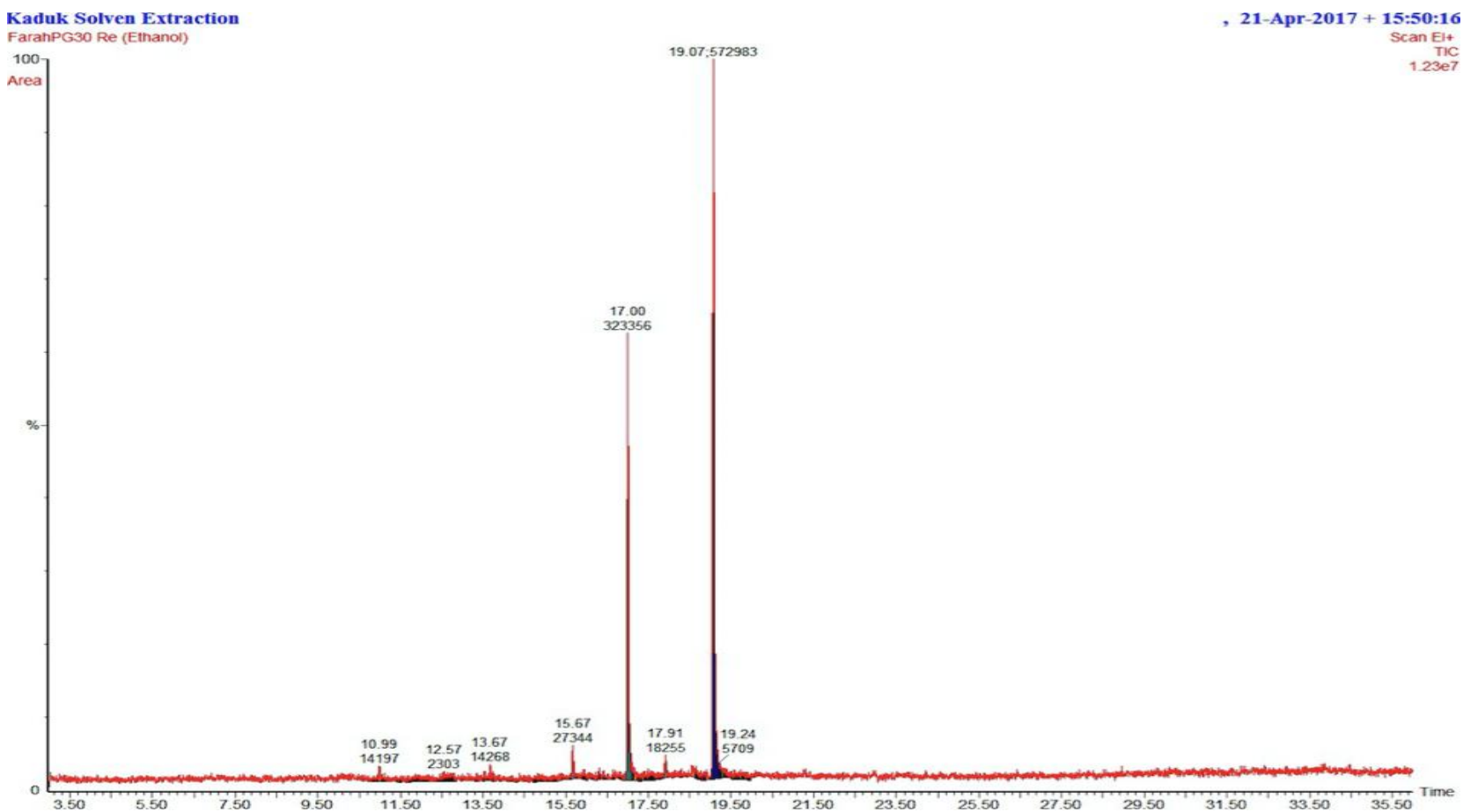

Figure 3: LC-MS chromatogram of phenolic compounds detected in methanolic extract of $P$. sarmentosum leaves.

\section{Determination of inhibition concentration value $\left(\mathrm{IC}_{50}\right)$ for half of cell population against $\boldsymbol{A}$. castellanii}

The inhibition concentration of PSLME for $50 \%$ of $A$. castellanii cell population (IC50 values) was obtained from the non-linear sigmoidal dose-response curve of percentage of cell population inhibition against the logarithm of PSLME concentration (Figure 4). The result showed that the plant leaves methanolic extract has good anti-amoebic properties against $A$. castellanii with the $\mathrm{IC}_{50}$ value of $74.62 \mu \mathrm{g} / \mathrm{mL}$.

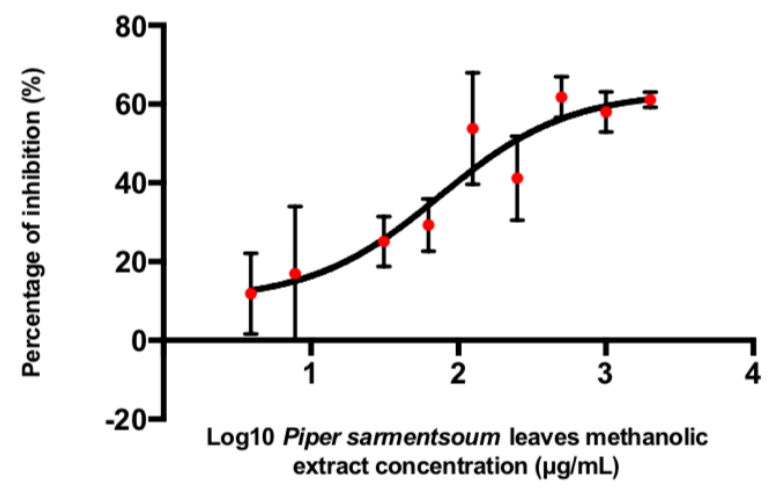

Figure 4: Non-linear dose response curve of $P$. sarmentosum leaves methanolic extract on $A$. castellanii. Error bars based on standard error of mean (SEM).

\section{Microscopy observation of $A$. castellanii cell morphology}

Distinctive alterations were exhibited in the PSLMEtreated $A$. castellanii cell morphology as shown in Figure 5. The healthy untreated cells or trophozoites had irregular shapes with distinct acanthopodia (Figure 5A). The presence of vacuoles and nucleus were easily detected in the trophozoites. Meanwhile, the extracttreated $A$. castellanii were reduced in size (Figure 5B). The cells were observed to be detached from the flat surface due to the shortening and loss of acanthopodia and became rounded. The features of the nucleus and contractile vacuoles were non-distinguishable. The chlorhexidine-treated cells were observed to cause more severe damages by significant reduction in the cell size and become spherical (Figure 5C). The formation of double cell membrane was also clearly detected.

\section{Measurement of cell confluence in axenic culture}

The aim of the analysis was to gain an overview image of the cell population and to analyse the cell confluence using ImageJ. It was noted that the cell confluence changes after $72 \mathrm{~h}$ treatment with the plant extract at $\mathrm{IC}_{50}$ values (Figure 6). Under the microscopy observation, the bright-orange dots represented the cells colonies while the dark space represented the space between the cells colonies. The higher the confluency of the cells observed, the lesser the dark space observed (Figure 6A). Based on the calculation of area fraction (AF), healthy untreated $A$. castellanii is classified as a confluent population as it 

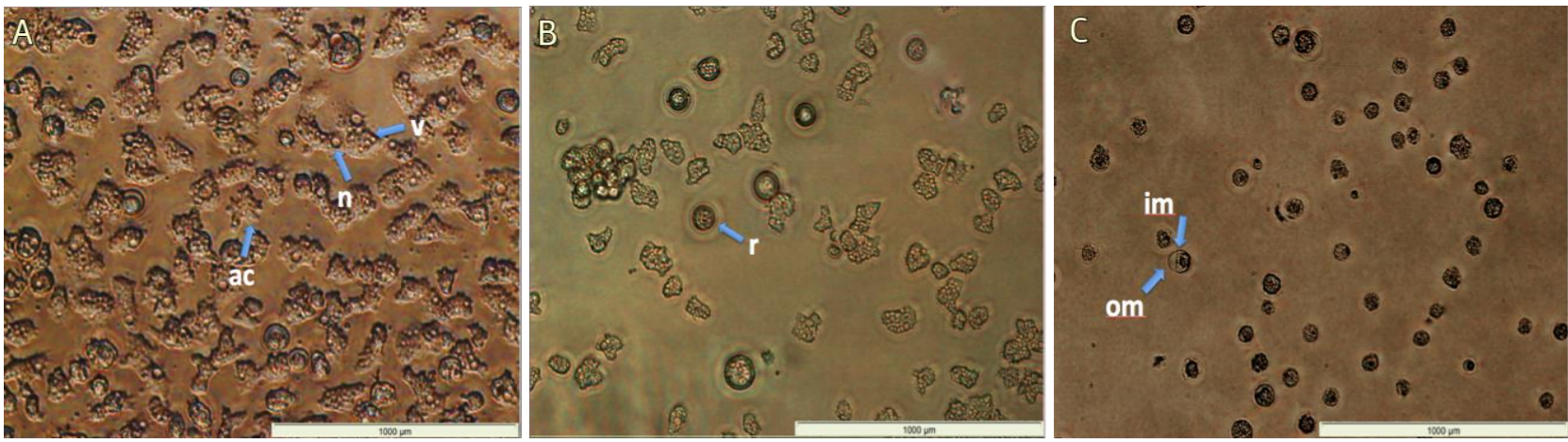

Figure 5: Inverted light microscopy images of $A$. castellanii (CCAP 1501/2A). (A) Untreated cells, (B) P. sarmentosum leaves extract-treated cells and $(C)$ Chlorhexidine-treated cells (positive control). Note: nucleus (n), vacuoles (v), acanthopodia (ac), rounded cell $(\mathrm{r})$, inner membrane $(\mathrm{im})$, outer membrane (om). Scale bars $1000 \mu \mathrm{m}$; magnification $20 \times$.

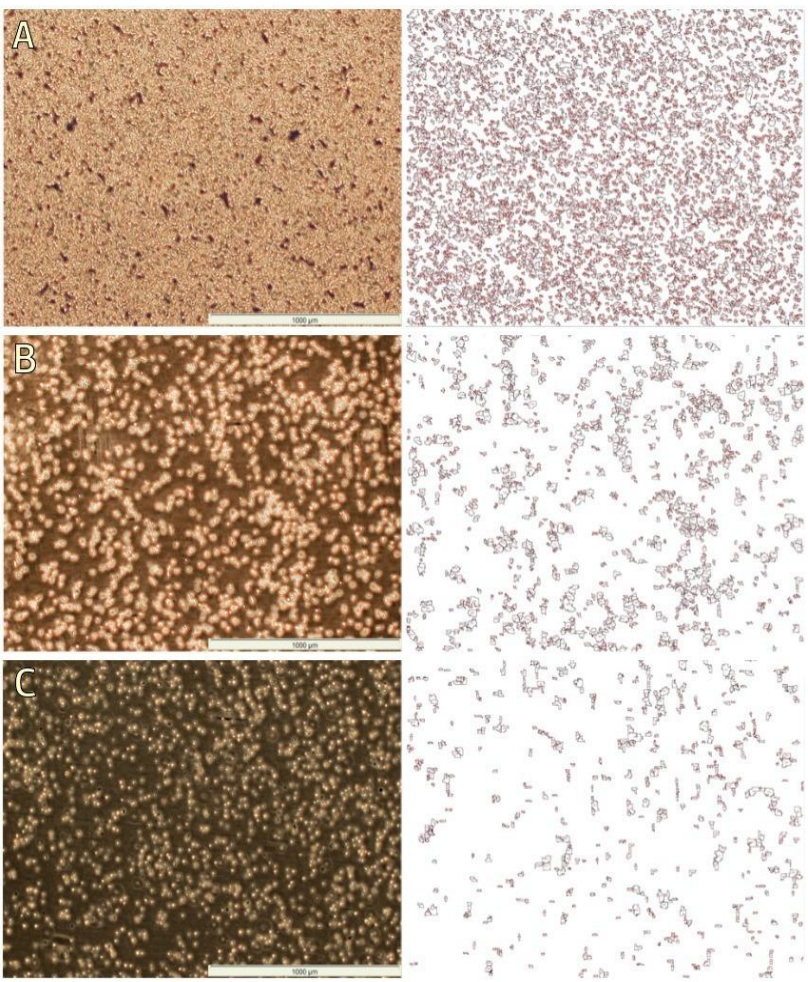

Figure 6: Measurement of $A$. castellanii (CCAP 1501/2A) cell confluency. Left image: Cells image under inverted light microscope (Scale bars $1000 \mu \mathrm{m}$; magnification 4x). Right image: Drawing of Area Fraction (AF) output generated by ImageJ software. (A) Untreated cells, (B) $P$. sarmentosum leaves extract-treated cells and (C) Chlorhexidine-treated cells (positive control).

achieved AF value of above 30 (31.99). However, the cell confluence was reduced when treated in PSLME with the $A F$ value of 19.06. The positive controls showed the lowest AF values of 5.76 .

\section{Scanning electron microscopy (SEM)}

Under SEM, healthy untreated $A$. castellanii cells displayed oval or triangular cell shape with the presence of many slender protrusions throughout the cells surface. Acanthopodia features were distinguishable indicated by the spine-like projections around the cell membrane. The presence of distinct vacuoles and nucleus embedded on the cell cytoplasm demonstrated that the amoeba lived in a favourable growth condition (Figure 7A). The PSLMEtreated Acanthamoeba was shrunken as the cell shape started to change from irregular into rounded form with smoother cell surface (Figure 7B). The vacuoles and nucleus were not visible. Meanwhile, the chlorhexidinetreated cell exhibited a complete cyst form with massive reduction in cell size, total loss of acanthopodia, vacuoles and nucleus (Figure 7C).
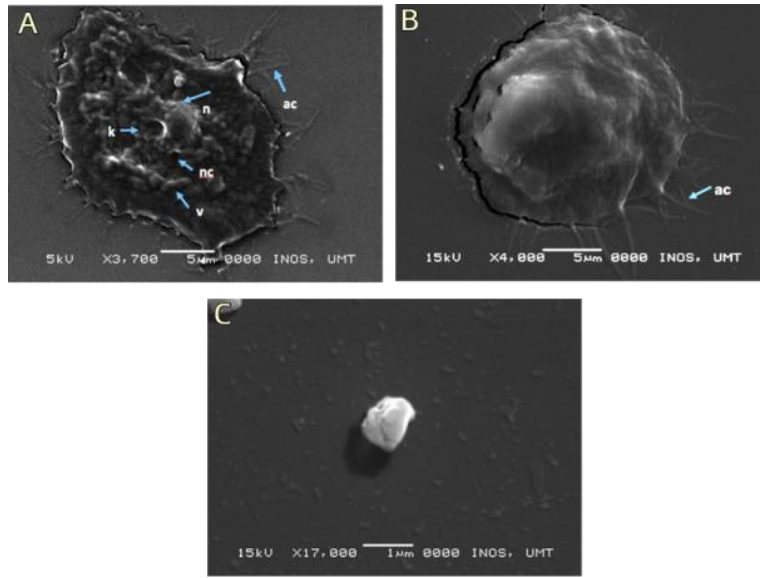

Figure 7: Scanning electron micrograph of $A$. castellanii (CCAP 1501/2A) single cell. (A) Healthy untreated cell (magnification 3700x), (B) PSLME-treated cell (magnification 4000x) and (C) Chlorhexidine-treated cell (positive control) (magnification 17000x). Note: acanthopodia (ac), nucleus (n), nucleolus (nc), karyosome $(k)$, vacuoles $(v)$. 


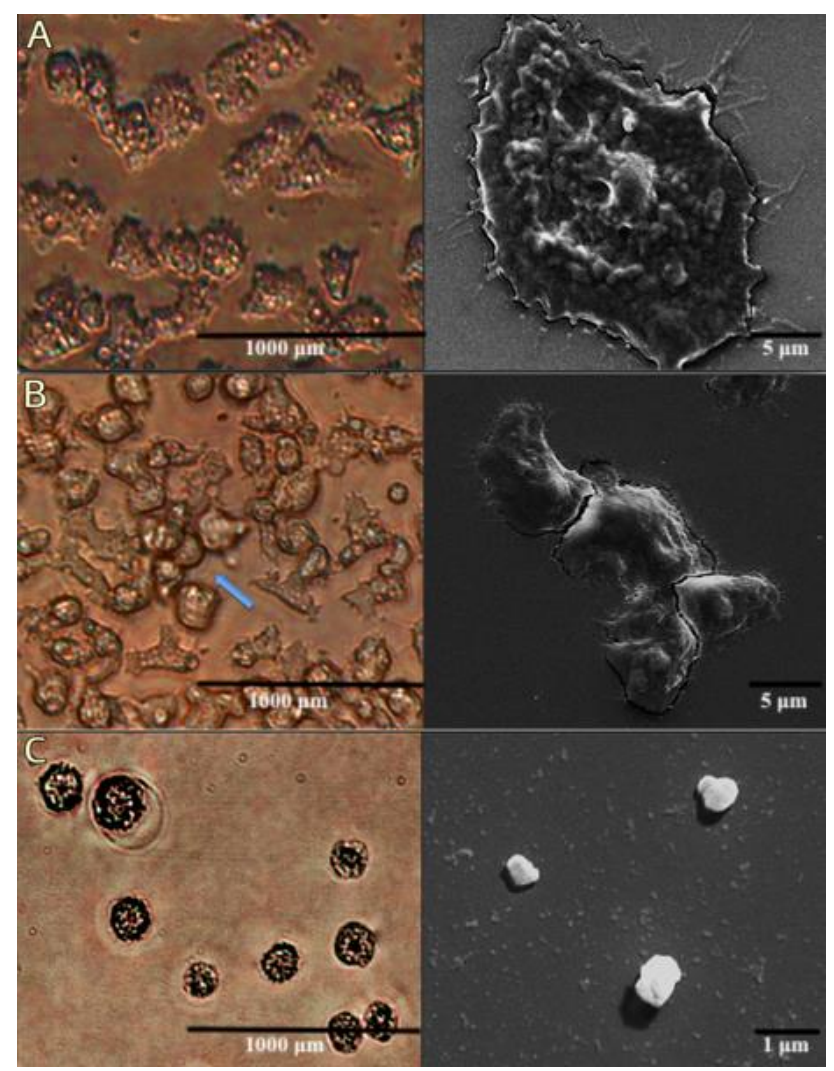

Figure 8: Zoomed-in microscopy image of $A$. castellanii (CCAP 1501/2A) morphology in axenic culture. Left image: Inverted light microscopy. Right image: Scanning electron microscopy. (A) Untreated cell, (B) $P$. sarmentosum leaves extract-treated cell and (C) Chlorhexidine-treated cell (positive control). Note: Arrow indicates clumping cells.

\section{Changes of Acanthamoeba morphology in axenic culture}

It was also observed that PSLME had altered the morphology of $A$. castellanii cells as the growth environment became unfavourable. Figure 8 shows the microscopic images of $A$. castellanii morphology in axenic culture. In the untreated condition, healthy $A$. castellanii grew as individual trophozoite cells (Figure 8A). Meanwhile, extract-treated cells were observed to grow in small clumps with their neighbouring cells. Chlorhexidinetreated Acanthamoeba displayed individual cysticappearance form of cell (Figure $8 \mathrm{C}$ ).

\section{Determination of membrane integrity}

The cells that were stained green to indicate that their membrane was intact, whereas cells that were stained orange or stained green with the granules in the cells stained red or orange indicated that the cell membranes' integrity had been compromised by the extract and therefore, they were classified as non-intact. In $A$. castellanii, the extract had caused membrane blebbing as indicated in Figure 9B. However, the PSLME-treated cells still maintain their membrane integrity. The positive control of chlorhexidine had caused more significant damage to cell membrane integrity, which was exhibited by the red fluorescence (Figure 9C).

Quantitative evaluation of membrane intactness was conducted. Figure 10 shows the bar charts of the percentage of membrane intactness. The results showed that without any treatment, almost all counted cells had intact membrane that gave the percentage of $94 \%$. The treatment of PSLME extract led to reduction in the percentage of the cells with intact membrane, which was $57 \%$. Chlorhexidine caused more severe effect than the extract with only $8 \% A$. castellanii left with intact cell membrane. T-test analysis showed that there was significant difference between cells with non-intact from intact membrane $(p<0.05)$ when treated in PSLME.

\section{DISCUSSION}

The selection of methanol as the solvent to extract phenolic compounds was based on its characteristic as a high polar solvent that could increase the solubility of phenolic components, therefore was capable of yielding high amount of phenolic compounds (Babbar et al.,
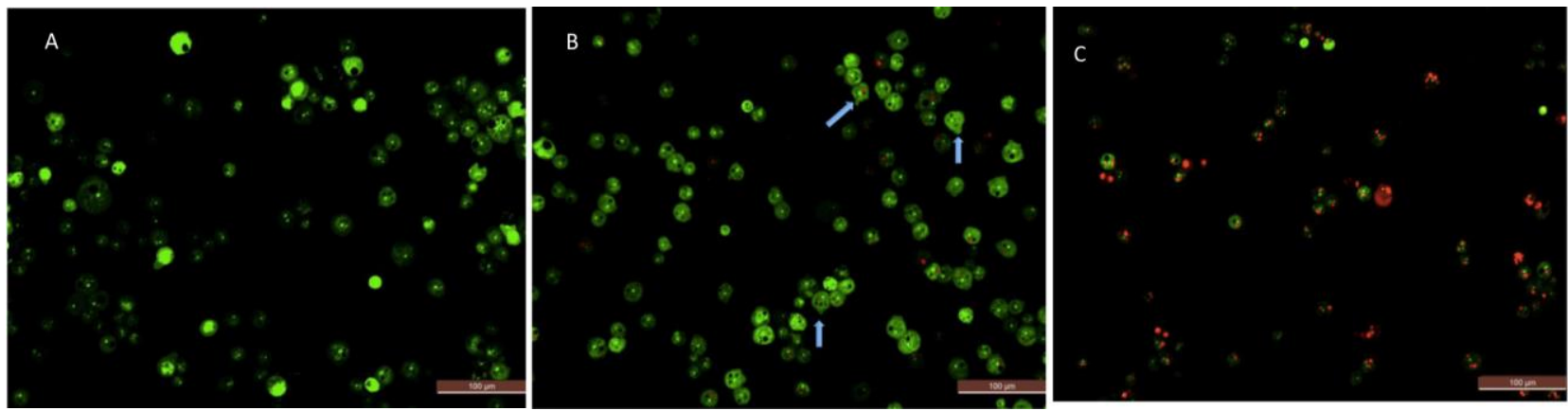

Figure 9: Fluorescence micrographs of $A$. castellanii (CCAP 1501/2A) stained with AO/PI dyes attached with zoomed-in cell image. (A) Untreated cells, (B) Extract treated-cells and (C) Chlorhexidine-treated cells (positive control). Note: Arrows indicate membrane blebbing. Scale bars: $100 \mu \mathrm{m}$; magnification $20 x$. 


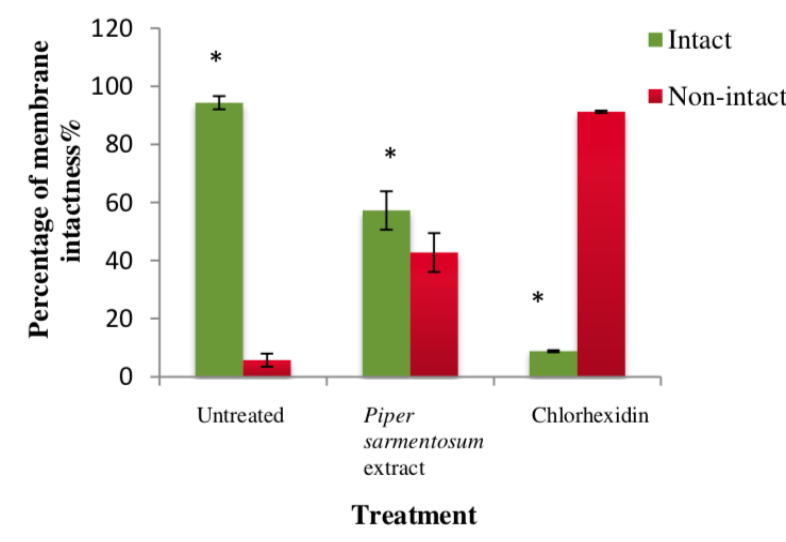

Figure 10: Percentage of membrane intactness of $A$. castellanii (CCAP 1501/2A). Data represent mean \pm standard error of mean from three replicates.

2012). According to Tsao (2010), most of phenolic compounds are classified as hydrophilic where the interaction between the polar sites of hydrophilic phenolic compounds and the solvent would occur, resulting in better solvation of the $P$. sarmentosum leaves bioactive phenolics in methanol.

The total phenolic compound (TPC) value in this study surpassed the yield from $P$. sarmentosum methanolic extract reported by Mustafa et al. (2010) with the values of $90.86 \mathrm{mg}$ [GAE]/g. Ugusman et al. (2012) also showed lower value of TPC yield of $91.02 \mathrm{mg}$ [GAE]/g obtained from $P$. sarmentosum aqueous extract. The reduced TPC observed in these previous studies emphasized the evidence that different extraction method and solvent could influence the yield of phenolic compounds (Babbar et al., 2012). In a study reported by Sárosi et al. (2011), plants grown in higher temperature and solar irradiance could accumulate higher amounts of phenolic compounds. As the sample in this study was cultivated under direct sun with periodically irrigation, this explains the highest amount of TPC in P. sarmentosum compared to the aforementioned previous studies.

Upon chromatography analyses, it was noted that there was no similar compounds detected between GCMS, RP-HPLC and LC-MS results. According to Dai and Mumper (2010), due to the complexity of the plant phenolics, different compounds may have different reactivity towards the assay solvents or reagents. The present GC-MS result was in accordance with the report by Rahman et al. (2014a), which found similar content of benzenepropanoic acid and asarone. The presence of asarone in the leaves of $P$. sarmentosum extract was also reported by many authors (Sim et al., 2009; Bactiar and Fahami, 2019; Zainol Abidin et al., 2020). Meanwhile, Tuntiwachwuttikul et al. (2006) had detected significant amount of benzenepropanoic acid in $P$. sarmentosum ethanolic extract. It is an intermediate in plant phenylpropanoid biosynthesis pathway. Detection of myristicine in $P$. sarmentosum was revealed in the study conducted by Rameshkumar et al. (2017) and Chaprapai and Chavasiri (2017). In other works, a study reported by Chieng et al. (2008) proved that the myristicine isolated from $P$. sarmentosum leaves oil has significant inhibitory activity against subterranean termite namely Coptotermes $\mathrm{sp}$. Additionally, the finding of methyleugenol in this study was validated by the reviews done by Sanusi et al. (2017) and Sun et al. (2020).

The presence of gallic acid, tannic acid, quercetin and naringenin in this study was supported the previous report by Rahman et al. (2014b) and Rahman et al. (2016) through RP-HPLC analysis. In addition, the reviews by Azelan et al. (2020) and Sun et al. (2020) also cited the presence of naringenin and quercetin in $P$. sarmentosum extract. According to several authors, $P$. sarmentosum is reported to contain the isolation of a number of amides and phenylpropanoids (Likhitwitayawuid et al., 1987; Masuda et al., 1991; Parmar et al., 1997; Stöhr et al., 1999; Rahman et al., 2016). These reports are in line with the findings from the LC-MS result, which also reported the same class of phenolic compounds. Other than that, the presence of tannin also corresponded to several findings by some authors in $P$. sarmentosum research (Chanwitheesuk et al., 2005; Hussain et al., 2009; Sanusi et al., 2017).

The anti-acanthamoebic activity of PSLME was classified as moderately active based on the cytotoxicity assays reported by Calzada et al. (2005). The antiprotozoal activities of medicinal plants are significantly active when the $\mathrm{IC}_{50}$ values are less than $38 \mu \mathrm{g} / \mathrm{mL}$ and moderately active when the $\mathrm{IC}_{50}$ values ranging from 41.7 to $100 \mu \mathrm{g} / \mathrm{mL}$. The presented $\mathrm{IC}_{50}$ values results were relatively low when compared to previous works that studied the anti-amoebic activities of varieties of medicinal plants extracts on $A$. castellanii. For example, the methanolic extracts of Passiflora caerulea, $P$. incarnate, and $P$. alata Curtis leaves and calluses gave the $\mathrm{IC}_{50}$ values ranges from 4 to $15 \mathrm{mg} / \mathrm{mL}$ (Hadaś et al., 2017), while the methanolic extract of Rubus ulmifolius showed IC 50 value of $61.79 \mathrm{mg} / \mathrm{mL}$ (Hajaji et al., 2017).

Naringenin and quercetin that were detected in the PSLME extract had been highlighted to possess strong antimicrobial, anti-inflammatory and antiprotozoal properties (Tasdemir et al., 2006; Jananie et al., 2011; Sre et al., 2012). Naringenin, which was isolated from Lippia graveolens Kunth had been shown to have higher antiprotozoal activity against Entamoeba histolytica, compared to other flavonoids of sakuranetin and cirsimaritin (Quintanilla-Licea et al., 2014). Meanwhile, in vivo test conducted by Wong et al. (2014) demonstrated that quercetin was the most potent compounds possessing leishmanicidal potential to combat the infection caused by Leishmania donovani in mouse models.

Maddox et al. (2009) emphasized that plant phenolic compounds exhibit significant antimicrobial activity against wide ranges of pathogenic microorganisms. According to Sanchez-Mata and Tardío (2016), the number of hydroxyl groups and its specific locations in the benzene ring are closely associated with the level of toxicity of a phenolic compound to microorganism, noting 
that the higher the hydroxylation process involved, the higher the inhibitory effect. The effect of hydroxylation can be seen for simple phenolics such as aspidinol. The presence of one hydroxyl group at C4' that is attached to one methoxyl group at $\mathrm{C7}^{\prime}$ in a phenolic compound is essential for anti-parasitic properties (Grecco et al., 2012).

Through microscopic morphological observation, PSLME caused distinctive alterations in the amoeba morphology with notable cells rounding as a result of shortening of acanthopodia. Acanthopodia is important in the cells movement for food and prey capturing, adhesion to surfaces and communication between cells (Bowers, 1969). The acanthopodia were observed to be thickened and elongated as an effort for cells to remain tightly attached to the surface substratum. SEM analysis revealed that PSLME-treated cells had altered acanthopodia. Acanthopodia is crucial in signal transmissions to induce the encystment process as the cells survival strategy by entering the dormant and resistance stages through diverse molecular and cellular modifications (Aguilar-Díaz et al., 2011).

In the presence of PSLME, the cells organelles especially nucleus and vacuoles were also shrunken and undistinguishable. At this stage, $A$. castellanii cells are metabolically inactive as they are undergoing encystment process. Shrunken nucleus causes the process of DNA replication and genetic information translation to cease. Additionally, the microscopy images of healthy $A$. castellanii also showed that numerous contractile vacuoles were embedded in the cell cytoplasm playing the key role in maintaining the cell osmotic regulation. In that process, the vacuoles contract to expel excess water from the inner part of the cells, simultaneously facilitates the cells to move and capture food (Bowers and Korn, 1974). The treatment with PSLME led to massive loss of vacuoles in $A$. castellanii, hence, causing disruption in the cell homeostasis, at the same time, diminishing the phagocytosis process for food and prey (Kusrini et al., 2016). Collectively, the morphology alterations in extracttreated $A$. castellanii lead to reduction in the cell population size indicated by low measurement of cell confluence.

The emission of bright green fluorescence is corresponding to the $\mathrm{AO}$ dye property that is readily permeable into the plasma membrane of Acanthamoeba cells (Hashim et al., 2015). Meanwhile, cells with nonintact membrane would allow the exclusion dye of $\mathrm{PI}$ to penetrate into the inner part of cells through the leakages and pores on the cell membrane (Schlicher et al., 2010). Therefore, $A$. castellanii emitted precipitates of orange or red fluorescence dispersed in the green cytoplasm due to the cytotoxic effect of PSLME. The previous study conducted by Nakisah et al. (2012) also showed similar result when $A$. castelanii was treated with Aaptos sp. extracts. The cells also became shrunken and smaller in size, which indicated an apoptosis has taken place.

\section{CONCLUSION}

By employing GC-MS, RP-HPLC and LC-MS, 33 phenolic compounds were identified in PSLME. The plant extract was found to be active in inhibiting the cells proliferation of $A$. castellanii in vitro indicated by low $\mathrm{IC}_{50}$ value of $74.62 \mu \mathrm{g} / \mathrm{mL}$. The cytotoxic effects are consistent in the subsequent microscopy analyses that demonstrated that the plant extract induces encystment process, hence making the cells to become inactive. The study provides the first preliminary data that describes the potential of phenolic content in PSLME of having potent inhibitory effects against $A$. castellanii. This fundamental research could provide new knowledge to benefit pharmacological field to treat Acanthamoeba-related diseases by utilizing phenolic compounds from $P$. sarmentosum.

\section{ACKNOWLEDGEMENTS}

This work was fully funded by Fundamental Research Grant Scheme (FRGS/1/2016/STG04/UIAM/02/2) for the financial support from the Ministry of Higher Education Malaysia (MOHE). Research facilities were provided by Kulliyyah of Science, International Islamic University Malaysia and Institute of Oceanography and Environment (INOS), University Malaysia Terengganu.

\section{REFERENCES}

Aguilar-Díaz, H., Carrero, J. C., Argüello-García, R., Laclette, J. P. and Morales-Montor, J. (2011). Cyst and encystment in protozoan parasites: Optimal targets for new life-cycle interrupting strategies? Trends in Parasitology 27(10), 450-458.

Atiax, E., Ahmad, F., Sirat, H. M. and Arbain, D. (2011). Antibacterial activity and cytotoxicity screening of Sumatran Kaduk (Piper sarmentosum Roxb.). Iranian Journal of Pharmacology and Therapeutics 10(1), 1-5.

Azelan, A., Taher, Z. M., Sasano, S., Ariga, T. and Aziz A. A. (2020). Chemical constituents and bioactivity of Piper sarmentosum: A mini review. Food Research 4(Suppl 2), 14-18.

Babbar, N., Oberoi, H. S., Sandhu, S. K. and Bhargav, V. K. (2012). Influence of different solvents in extraction of phenolic compounds from vegetable residues and their evaluation as natural sources of antioxidants. Journal of Food Science and Technology 51(10), 2568-2575.

Bactiar, C. F. and Fahami, N. A. M. (2019). LC-MS analysis of phytocomponents in the methanol extract of Piper sarmentosum leaves. Pharmacognosy Journal 11(5), 1071-1076.

Bowers, B. and Korn, E. D. (1969). The fine structure of Acanthamoeba castellanii (Neff strain): II Encystment. Journal of Cell Biology 41(3), 786-805.

Bowers, B. and Korn, E. D. (1974). Localization of lipophosphonoglycan on both sides of Acanthamoeba plasma membrane. Journal of Cell Biology 62(2), 533540. 
Busschots, S., O'Toole, S., O'Leary, J. J. and Stordal, B. (2015). Non-invasive and non-destructive measurements of confluence in cultured adherent cell lines. MethodsX 2, 8-13.

Calzada, F., Cervantes-Martínez, J. A. and YépezMulia, L. (2005). In vitro antiprotozoal activity from the roots of Geranium mexicanum and its constituents on Entamoeba histolytica and Giardia lamblia. Journal of Ethnopharmacology 98(1-2), 191-193.

Chanprapai, P. and Chavasiri, W. (2017). Antimicrobial activity from Piper sarmentosum Roxb. against rice pathogenic bacteria and fungi. Journal of Integrative Agriculture 16(11), 2513-2524.

Chanwitheesuk, A., Teerawutgulrag, A. and Rakariyatham, N. (2005). Screening of antioxidant activity and antioxidant compounds of some edible plants of Thailand. Food Chemistry 92(3), 491-497.

Chieng, T. C., Assim, Z. B. and Fasihuddin, B. A. (2008). Toxicity and antitermite activities of the essential oils from Piper sarmentosum. The Malaysian Journal of Analytical Sciences 12(1), 234-238.

Dai, J. and Mumper, R. J. (2010). Plant phenolics: Extraction, analysis and their antioxidant and anticancer properties. Molecules 15(10), 7313-7352.

Dykes, L. and Rooney, L. W. (2007). Phenolic compounds in cereal grains and their health benefits. Cereal Foods World 52(3), 105-111.

Grecco, S. S., Ferreira, M. J. P., Romoff, P., Favero, 0. A. and Lago, J. H. G. (2012). Phenolic derivatives from Baccharis retusa DC. (Asteraceae). Biochemical Systematics and Ecology 42, 21-24.

Hadaś, E., Derda, M. and Cholewiński, M. (2017). Evaluation of the effectiveness of tea tree oil in treatment of Acanthamoeba infection. Parasitology Research 116(3), 997-1001.

Hajaji, S., Jabri, M., Sifaoui, I., López-Arencibia, A., Reyes-Batlle, M., B'chir, F., Valladares, B., Pinero, J. E., Lorenzo-Morales, J. and Akkari, H. (2017). Amoebicidal, antimicrobial and in vitro ROS scavenging activities of Tunisian Rubus ulmifolius Schott, methanolic extract. Experimental Parasitology 183, 224-230.

Hashim, F., Rahman, N. A. A. and Amin, N. M. (2015). Morphological analysis on the toxic effect of manganese on Acanthamoeba sp. isolated from Setiu Wetland, Terengganu: An in vitro study. Procedia Environmental Sciences 30, 15-20.

Hussain, K., Hashmi, F. K., Latif, A., Ismail, Z. and Sadikun, A. (2012). A review of the literature and latest advances in research of Piper sarmentosum. Pharmaceutical Biology 50(8), 1045-1052.

Hussain, K., Ismail, Z., Sadikun, A. and Ibrahim, P. (2009). Antioxidant, anti-TB activities, phenolic and amide contents of standardised extracts of Piper sarmentosum Roxb. Natural Product Research 23(3), 238-249.

Jananie, R. K., Priya, V. and Vijayalakshmi, K. (2011). In vitro assessment of free radical scavenging activity of Cynodon dactylon. Journal of Chemical and Pharmaceutical Research 3(4), 647-654.
Kamel, M. A. G., Faridah, H., Yusof, S., Norazah, A. and Nakisah, M. A. (2005). A case of non-contact lens related Acanthamoeba keratitis in Malaysia. Malaysian Journal of Microbiology 1(2), 58-60.

Khoddami, A., Wilkes, M. A. and Roberts, T. H. (2013). Techniques for analysis of plant phenolic compounds. Molecules 18(3), 2328-2375.

Kusrini, E., Hashim, F., Azmi, W. N. N. W. N., Amin, N. M. and Estuningtyas, A. (2016). A novel antiamoebic agent against Acanthamoeba sp. - A causative agent for eye keratitis infection. Spectrochimica Acta Part A: Molecular and Biomolecular Spectroscopy 153, 714721.

Likhitwitayawuid, K., Ruangrungsi, N., Lange, G. L. and Decicco, C. P. (1987). Structural elucidation and synthesis of new components isolated from Piper sarmentosum (Piperaceae). Tetrahedron 43(16), 3689-3694.

Lorenzo-Morales, J., Ortega-Rivas, A., Foronda, P., Martínez, E. and Valladares, B. (2005). Isolation and identification of pathogenic Acanthamoeba strains in Tenerife, Canary Islands, Spain from water sources. Parasitology Research 95(4), 273-277.

Maddox, C. E., Laur, L. M. and Tian, L. (2009). Antibacterial activity of phenolic compounds against the phytopathogen Xylella fastidiosa. Current Microbiology 60(1), 53-58.

Masuda, T., Inazumi, A., Yamada, Y., Padolina, W. G., Kikuzaki, H. and Nakatani, N. (1991). Antimicrobial phenylpropanoids from Piper sarmentosum. Phytochemistry 30(10), 3227-3228.

Mustafa, R. A., Hamid, A. A., Mohamed, S. and Abu Bakar, F. (2010). Total phenolic compounds, flavonoids, and radical scavenging activity of 21 selected tropical plants. Journal of Food Science 75(1), 28-35.

Nakisah, M. A., Muryany, M. Y. I., Fatimah, H., Fadilah, R. N., Zalilawati, M. R., Khamsah, S. and Habsah, M. (2012). Anti-amoebic properties of a Malaysian marine sponge Aaptos sp. on Acanthamoeba castellanii. World Journal of Microbiology and Biotechnology 28(3), 1237-1244.

Parmar, V. S., Jain, S. C., Bisht, K. S., Jain, R., Taneja, P., Jha, A., Tyagi, O., Prasad, A., Wengel, J., Olsen, C. and Boll, P. (1997). Phytochemistry of the genus Piper. Phytochemistry 46(4), 597-673.

Pieroni, L. G., de Rezende, F. M., Ximenes, V. F. and Dokkedal, A. L. (2011). Antioxidant activity and total phenols from the methanolic extract of Miconia albicans (Sw.) Triana leaves. Molecules 16(11), 94399450.

Quintanilla-Licea, R., Mata-Cárdenas, B. D., VargasVillarreal, J., Bazaldúa-Rodríguez, A. F., Kavimngeles-Hernández, I., Garza-González, J. N. and Hernández-García, M. E. (2014). Antiprotozoal activity against Entamoeba histolytica of plants used in northeast Mexican traditional medicine. Bioactive compounds from Lippia graveolens and Ruta chalepensis. Molecules 19(12), 21044-21065. 
Rahman, S. F. S. A., Sijam, K., Omar, D. and Wahab, M. Z. (2016). Identification of phenolic compounds and evaluation of antibacterial properties of Piper sarmentosum Roxb. against rice pathogenic bacteria. Malaysian Journal of Microbiology 12(6), 475-484.

Rahman, S. F. S. A., Sijam, K. and Omar, D. (2014a). Chemical composition of Piper sarmentosum extracts and antibacterial activity against the plant pathogenic bacteria Pseudomonas fuscovaginae and Xanthomonas oryzae pv. oryzae. Journal of Plant Diseases and Protection 121(6), 237-242.

Rahman, S. F. S. A., Sijam, K. and Omar, D. (2014b). Identification and antibacterial activity of phenolic compounds in crude extracts of Piper sarmentosum (Kadok). Journal of Pure and Applied Microbiology 8(2), 483-490.

Rahman, S. F. S. A., Sijam, K. and Omar, D. (2016). Antibacterial activity of the crude extract of Piper sarmentosum against Pseudomonas fuscovaginae. International Journal of Applied Biology and Pharmaceutical Technology 7(1), 67-72.

Rameshkumar, K. B., Nandu, T. G., Anu Aravind, A. P., Mathew, S. P. and Shiburaj, S. (2017). Chemical composition and FtsZ GTPase inhibiting activity of the essential oil of Piper sarmentosum from Andaman Islands, India. Journal of Essential Oil Research 29(5), 430-435.

Sanchez-Mata, M. D. C. and Tardío, J. (2016). Mediterranean Wild Edible Plants: Ethnobotany and Food Composition Tables. Springer, New York.

Sanusi, N. A., Umar, R. A., Zahary, M. N., Rohin, M. A. K., Pauzi, M. R. and Ismail, S. (2017). Chemical compositions and antimicrobial properties of Piper sarmentosum - A review. IOSR Journal of Dental and Medical Sciences 16(8), 62-65.

Sárosi, S., Bernáth, J., Burchi, G., Antonetti, M., Bertoli, A., Pistelli, L. and Benvenuti, S. (2011). Effects of different plant origins and climate conditions on the total phenolic content and total antioxidant capacity of self-heal (Prunella vulgaris L.). Acta Horticulturae 925, 49-55.

Schlicher, R. K., Hutcheson, J. D., Radhakrishna, H., Apkarian, R. P. and Prausnitz, M. R. (2010). Changes in cell morphology due to plasma membrane wounding by acoustic cavitation. Ultrasound in Medicine and Biology 36(4), 677-692.

Siddiqui, R. and Khan, N. A. (2012). Biology and pathogenesis of Acanthamoeba. Parasites and Vectors 5, 6.

Sim, K. M., Mak, C. N. and Ho, L. P. (2009). A new amide alkaloid from the leaves of Piper sarmentosum. Journal of Asian Natural Products Research 11(8), 757-760.

Soto-Vaca, A., Gutierrez, A., Losso, J. N., Xu, Z. and Finley, J. W. (2012). Evolution of phenolic compounds from color and flavor problems to health benefits. Journal of Agricultural and Food Chemistry 60(27), 6658-6677.

Sre, P. R. R., Sheila, T. and Murugesan, K. (2012). Phytochemical screening and "in-vitro" and anti- oxidant activity of methanolic root extract of Erythrina indica. Asian Pacific Journal of Tropical Biomedicine 2(Suppl 3), S1696-S1700.

Stöhr, J. R., Xiao, P. G. and Bauer, R. (1999). Isobutylamides and a new methylbutylamide from Piper sarmentosum. Planta Medica 65(2), 175-177.

Sun, X., Chen, W., Dai, W., Xin, H., Rahmand, K., Wang, Y., Zhang, J., Zhang, S., Xu, L. and Han, T. (2020). Piper sarmentosum Roxb.: A review on its botany, traditional uses, phytochemistry, and pharmacological activities. Journal of Ethnopharmacology 263, 112897.

Tasdemir, D., Kaiser, M., Brun, R., Yardley, V., Schmidt, T. J., Tosun, F. and Ruedi, P. (2006). Antitrypanosomal and antileishmanial activities of flavonoids and their analogues: In vitro, in vivo, structure-activity relationship, and quantitative structure-activity relationship studies. Antimicrobial Agents and Chemotherapy 50(4), 1352-1364.

Tsao, R. (2010). Chemistry and biochemistry of dietary polyphenols. Nutrients 2(12), 1231-1246.

Tsvetkova, N., Schild, M., Panaiotov, S., KurdovaMintcheva, R., Gottstein, B., Walochnik, J., Aspöck, H., Lucas, M. S. and Müller, N. (2004). The identification of free-living environmental isolates of amoebae from Bulgaria. Parasitology Research 92(5), 405-413.

Tuntiwachwuttikul, P., Phansa, P., Pootaeng-on, Y. and Taylor, W. C. (2006). Chemical constituents of the roots of Piper sarmentosum. Chemical and Pharmaceutical Bulletin 54(2), 149-151.

Ugusman, A., Zakaria, Z., Hui, C. K., Nordin, N. A. M. M. and Mahdy, Z. A. (2012). Flavonoids of Piper sarmentosum and its cytoprotective effects against oxidative stress. Experimental and Clinical Sciences Journal 11, 705-714.

Wong, I. L. K., Chan, K. F., Chen, Y. F., Lun, Z. R., Chan, T. H. and Chow, L. M. C. (2014). In vitro and in vivo efficacy of novel flavonoid dimers against cutaneous leishmaniasis. Antimicrobial Agents and Chemotherapy 58(6), 3379-3388.

Wright, C. W., O'Neill, M. J., Phillipson, J. D. and Warhurst, D. C. (1988). Use of microdilution to assess in vitro antiamoebic activities of Brucea javanica fruits, Simarouba amara stem, and a number of quassinoids. Antimicrobial Agents and Chemotherapy 32(11), 1725-1729.

Zainol Abidin, I. Z., Fazry, S., Jamar, N. H., Dyari, H. R. E., Ariffin, Z. Z., Johari, A. N., Ashaari, N. S., Johari, N. A., Abdul Wahab, R. M. and Ariffin, S. H. Z. (2020). The effects of Piper sarmentosum aqueous extracts on zebrafish (Danio rerio) embryos and caudal fin tissue regeneration. Scientific Reports 10, 14165.

Zakaria, Z. A., Patahuddin, H., Mohamad, A. S., Israf, D. A. and Sulaiman, M. R. (2010). In vivo antinociceptive and anti-inflammatory activities of the aqueous extract of the leaves of Piper sarmentosum, Journal of Ethnopharmacology 128(1), 42-48. 